\title{
Pediatrics and psychology in Argentina: a historical study (1930-1960)
}

\author{
Ana S. Briolotti, Ph. D. ${ }^{a}$
}

\begin{abstract}
In this article, I will analyze the relationship between pediatrics and psychology in Argentina in the 1930-1960 period. This article describes how the sanitary, social, and medical approach typical of our local pediatric traditionlaid the foundation for a dialog with psychology, captured by the innovation proposals emerged in the mid1950s. It also addresses certain specific use of psychology in medical interventions resulting from the need to understand and solve specific problems regarding growth and development during early childhood. To conclude, it points out that, although pediatrics has shown a progressive reconciliation with psychology throughout the studied period, it failed to have far-reaching implications.

Key words: history, pediatrics, psychology, Argentina.
\end{abstract}

a. Universidad

Nacional de

Quilmes (UNQ),

Department of

Social Sciences,

National Scientific

and Technical

Research Council

(Consejo Nacional de Investigaciones Científicas

y Técnicas,

CONICET), Bernal,

Buenos Aires,

Argentina.

E-mail address:

Ana S. Briolotti, Ph. D.: anabriolotti@conicet. gov.ar

\section{Funding:}

Postdoctoral internal fellowship granted by the National Scientific and Technical Research Council (Consejo Nacional de Investigaciones Científicas y Técnicas, CONICET).

Conflict of interest: None.

Received: 6-11-2020 Accepted: 7-7-2020 http: / / dx.doi.org/10.5546/ aap.2020.eng.427

To cite: Briolotti AS. Pediatrics and psychology in Argentina: a historical study (1930-1960). Arch Argent Pediatr 2020;118(6):427-432.

\section{INTRODUCTION}

Cultural and social dimensions are inherent to medicine; however, in the field of pediatrics, they are constituent elements. ${ }^{1}$ Actually, considering the relationship between medicine and society, pediatrics has been a key specialty in the development of prospective interventions aimed at optimizing national human resources. Such characteristic may be redirected towards certain matrix typical of Western medicine which, close to the $19^{\text {th }}$ century, became consolidated as a "nationalized" discipline focused on improving population health. ${ }^{2}$ In that context, childhood was considered a vital period that was highly relevant for the future because practically anything that occurs in this period of life would have consequences in adulthood. For this reason, anything done in pursuit of child health was ultimately a bet on the future of humankind.

In addition to studying childhood diseases and monitoring biological development, pediatrics took an interest in weighing psychological development and established criteria regarding what might have been considered a "normal" development. This meant a dialog with psychology in the context of a long-standing medical tradition targeted at making an intervention in society in order to change certain habits and settle new behaviors and representations associated with health, physical and mental well-being, and social advances. ${ }^{3,4}$

This article analyzes the relationship between pediatrics and psychology in Argentina from the 1930s to the 1960s. During this period, graduate education left psychology out of university curricular contents almost entirely. ${ }^{5-8}$ However, over these decades, knowledge about psychology became gradually more significant in medical discourse, in line with an increasingly complex understanding of children as an object of study and medical intervention.

The theoretical-methodological approach adopted here combines the contributions made by the critical history of psychology and historical studies about health, disease, and medicine. The former proposes a method aimed at making the external aspects of psychology visible by highlighting that scientific research depends on the material conditions offered by society and that research design and results depend on the social conditions in which it is developed. Based on this approach, the history of psychology is not a description of the scientific advances 
of individuals or schools of thought based on the personal and independent interests of settingspecific cultural, social, political, and financial factors. ${ }^{9-12}$ Since this article will focus on the relationship between psychology and medicine, it is necessary to consider the history of the latter. In this regard, historical studies about health, disease, and medicine are particularly relevant because they have renewed the more traditional perspective focused on great names and medical science advances. There, biomedical aspects intertwine with the subjective domain of actors and are linked to social, cultural, political, and financial phenomena. ${ }^{13-15}$

This investigation is the result of a hypothesis that proposed that, throughout the studied period, psychological knowledge became gradually more significant in medical discourse, in line with a "psychologized" understanding of child development. This process was connected to the dissemination of "psy-" discourses in the Western civilization. In such setting, "psy-" concepts and techniques provided solutions to different problems and key interpretations of different human phenomena. ${ }^{12,16-18}$ In relation to pediatrics, some of its distinctive features laid the foundation for a dialog with psychology, captured by discipline innovation proposals and specific psychology uses in medical interventions regarding growth and development during early childhood ( $0-3$ years).

\section{Pediatrics, hygiene, and social medicine: towards a dialog with psychological knowledge}

In the 1950s, a sort of new paradigm emerged, based on which, local pediatrics sought to integrate patient psychosocial aspects to its approach. However, such change did not entail a complete renovation of pediatrics by psychology; instead, it took place seamlessly in a series of principles typical of the specialty. From the beginning, local pediatrics was not restricted to the management of childhood diseases, it also promoted preventive interventions. Such actions occurred in the setting of a sanitary, eugenic, social, and medical project based on the idea that a healthy, productive individual was the best capital of a country. ${ }^{19}$ Therefore, the institutionalization of pediatrics took place in close relation with hygiene and eugenics, a discipline that adopted a positive, environmental, Latin profile in Argentina. ${ }^{20}$ On its side, hygiene played an important role as an instrument at the service of the "Argentine race improvement" ${ }^{21}$ and thus connected with eugenics. It had a prominent role in the development of the pediatric field, at a local and international level, and allowed to approach children in the setting of a social and biological health project.

After World War II, when the eugenic rhetoric of race improvement lessened sharply, the impression of the sanitary discourse was still present in local pediatrics. In the mid1950s, several authors reasserted the tradition according to which pediatrics should maintain a comprehensive and consistent relation with physical and mental hygiene. ${ }^{22-24}$ In the field of psychology, such sanitary profile of pediatrics established a close coordination with the concepts of mental hygiene, a movement that emerged in the United States in the early $20^{\text {th }}$ century and became consolidated in Argentina by the 1930s with the creation of the Argentine League for Mental Hygiene.

Mental hygiene discourse, structured around the concept of prophylaxis, recognized two theme cores: $:^{25}$ the early detection of the condition and the thesis of maladaptive triggering of psychological disorders, which considered the role of social factors in the onset of mental disease (however, it did not address the hereditary hypothesis). Mental hygiene was envisaged as a modern instrument that Argentine physicians could use to translate the reforming vocation that characterized their profession from the beginning into specific actions. ${ }^{26}$ In addition, pediatrics demonstrated that mental hygiene was not a topic of interest unique to psychiatry. Great names like Mamerto Acuña and Juan P. Garrahan promoted the creation of organizations like the Mental Hygiene Clinic (then known as the Center for Pediatric Psychology and Psychiatry), which started functioning in 1934 at the Institute for Pediatrics and Newborn Infant Care of Hospital de Clínicas.

This sanitary approach coexisted with the clinical approach and was the basis for the acceptance of psychological knowledge and practice. In the interwar period, the image of a world undergoing a moral and existential crisis, together with the tendency towards hyperspecialization, proposed a series of requirements for medicine: faced with a compartmentalized vision, it had to regain perspective, meditation, and intuition as guidance for medical practice. In the midst of a crisis of values, reintroducing the study 
of a spiritual domain into medical humanism through a comprehensive contact with disease demonstrated that human beings could not be reduced to their biological domain. ${ }^{27}$ In that period, part of the medical field echoed "medical holism," 28 a movement disseminated across Europe and the United States in the 1920s and 1930s which combined different trends opposed to reductionism. (The trends that were part of this movement included German constitutional medicine, Italian biotypology, North American psychobiology, French medical humanism, psychosomatic medicine, Christian humanism, neohippocratic medicine, and homeopathy).

By the mid-20 $0^{\text {th }}$ century, these ideas resurfaced during the second post-war period, when international organizations and national governments established an agenda of problems related to the rights of the child and strengthened their commitment to the physical and emotional well-being of new generations. In Argentina, these ideas established a series of requirements that, in the middle of the "psychologization" of Western societies, were picked up by psychosomatic medicine. The introduction of this trend was a turning point that allowed pediatrics to project new horizons for pediatric practice. The field of "psychosomatic pediatrics" described by Florencio Escardó ${ }^{29}$ and the "new puericulture" proposed by Juan Pedro Garrahan $^{30-32}$ are an exemplary reflection of how this discipline has reshaped itself. In the 1950s, both defined a pediatrics project that proposed a comprehensive approach to children as part of a family responsible for their physical health, but also, and above all, their future social integration and the quality and balance of the bonds they may establish. These two pediatricians introduced contributions made by psychology without making pediatrics lose its specificity and without undermining medical authority, in a time when psychology started to shape up as an autonomous profession and when psychoanalysis gained more and more visibility in the Argentine society.

\section{Knowledge, practice, and techniques: uses of psychology in Argentine pediatrics}

As mentioned above, the purpose of the approach proposed here is to understand the development of scientific disciplines in relation to the social context. In this regard, it would be biased to make an analysis of pediatricians' approach to psychology as a result of personal interests or as a "mechanical" response to the winds of change brought about by the second post-war period. Instead, such approach is considered to have been mainly encouraged by interconnected problems that resulted in a dialog between these two fields of knowledge.

Actually, it is possible to note that pediatrics approached psychology not just because of "medical holism," but also because of the need to solve a series of specific problems that were, in one way or another, linked to broader social issues. An example of this is the establishment of "normal" growth and development parameters in a young country mainly populated by immigrants. In this context, a demand for anthropometric and psychological development studies emerged in relation to eugenic measures and a concern for establishing the racial foundations of national identity. In turn, such anthropometric display took place in a context marked by the development of statistics, a broadening of state interventions, and the implementation of social policies aimed at fighting childhood mortality and promoting natality. ${ }^{33-35}$ Thus, in some Infant Dispensaries of Buenos Aires, psychosensory development was measured using the test created by Viennese psychologist Charlotte Bühler ${ }^{36}$ for descriptive purposes and based on mental hygiene principles, as a tool to guide interventions aimed at modifying environmental variables that affected development. Later, towards the 1960s, the scale used was that developed by American psychologist and pediatrician Arnold Gesell. ${ }^{37-39}$

Although both tests shared several features, their objectives were different: the studies that used the Gesell Development Schedule were aimed at establishing the incidence of environmental factors (nutrition, rearing setting) in the course of development. In all truth, during the studied period, there was certain tension between the maturational theory that subordinated psychological manifestations to neurological development $\mathrm{t}^{40}$ and the environmentalist perspective. Over the years, the balance tilted in favor of the latter of these two poles in tension.

Such interest in assessing the incidence of the environment cannot be separated from the dissemination of studies about the psychological consequences of emotional deprivation in the first years of life and the emergence of a biopsychosocial understanding of children brought about by the Mental Health movement that appeared during the second post-war period, which paid special attention to the dynamics of 
relationships where development took place. ${ }^{41}$ The same reasons allowed to redesign the concept of a long-standing problem: the physical and psychological consequences of children's stay in hospitals and childcare institutions, which many times resulted in what was known as "hospitalism". ${ }^{42}$ Hospitalism put the naturalist medical trend in check by suggesting the contradiction that, even with the best technical advances and trained staff, the hospital setting accelerated a child's deterioration towards potential death. In turn, it showed the deep link that seemed to exist between development and certain psychological well-being resulting from individualized care and psychological stimulation. The report by British psychiatrist and psychoanalyst John Bowlby for the World Health Organization ${ }^{43}$ received a large echo among local pediatricians and was a key element in the implementation of novel devices in Argentina, such as the rooming-in practice for mother and child proposed by Escardó.

One of the issues made clear by hospitalism was that an adequate nutrition and good sanitary conditions, which were many times better than those at home, were not enough to warrant a normal growth and development. Nutrition, a key subject matter in pediatrics, was another topic for the dialog between medicine and psychology. A paradigmatic problem resulting from such dialog was the so-called "mental anorexia" or "psychological loss of appetite," an enigmatic disorder that became a common reason for consultation in the mid-1930s. ${ }^{44-47}$ At the beginning of the studied period, the main hypothesis suggested a connection between an inherited neuropathic condition ${ }^{48}$ and educational shortcomings. This entailed a psychological explanation that attributed anorexia to unpleasant stimuli that promoted the development of a conditioned food rejection response. The principles of classical behaviorism suggested that a child's eating behavior could be molded based on the development and reinforcement of good habits. ${ }^{46,49,50}$

The proposed interventions combined the administration of drugs and vitamins with educational indications based on mental hygiene that reflected a representation of child psyche as an instance directly influenced by the environment, even if determined by inheritance. Since the 1950s, the interpretation of this problem somehow shifted towards an interpretation in the light of children's emotional development and relationship with their families. ${ }^{51,52}$ In this setting, the psychoanalytic theory of infantile sexuality gained special relevance and complemented the Pavlovian approach centered on physiological research. Thus, breastfeeding became essential, not only for its nutritional qualities, always underlined by pediatricians, but also for the emotional and psychosexual dynamics it entailed, which added an extra value as emotional support to relieve anxiety and contributed to shaping a balanced personality. ${ }^{30,53}$ In a world that aimed to leave totalitarianism behind, such dialog with psychological theories expected to put emotions and the importance of warranting children the possibility of "channeling their instincts" back in place in an environment that recreated the democratic order projected globally in the family setting.

\section{CONCLUSION}

Throughout the proposed study period, it can be observed that the sanitary, medical, and social profile that characterized pediatrics favored an increasing dialog with psychological knowledge, which reached an early systematization towards the mid-1950s in the form of proposals like the ones made by Garrahan and Escardó. They were aimed at overcoming the limits of organicist approaches and developing a more sophisticated approach that transcended the mere concern for children's survival. The resulting exchanges between both disciplines led to interventions regarding specific topics and problems, which found a way of confining and explaining themselves under "psy-" terms. If such psychological approach was possible and chosen by certain pediatricians, undoubtedly, it may be understood as resulting in a context that, at a local level, witnessed the convergence of psychosomatic medicine, the rights of the child, better quality of life conditions for the population, and certain sense of renewal that would take place in the 1960s.

It is worth pointing out that many of the proposed ideas and practices were not rapidly undertaken and even generated resistance among health care providers. One of the clearest examples was the rejection of the roomingin practice proposed by Escardó. ${ }^{54}$ With this clarification in mind, it is necessary to highlight that, although pediatrics has shown a progressive reconciliation with psychology throughout the studied period, it failed to have far-reaching implications. Therefore, it may be suggested 
that physicians progressed towards outlining a biopsychosocial approach without specific training or clear therapeutic tools, which however seemed necessary to play a more effective role adjusted to a study object, i.e. children, whose understanding became more complex in the period studied here. In addition, this contributed to the process of recognizing and legitimizing psychological knowledge within the scientific community. In subsequent years, with the graduation of the first psychologists and their introduction into health care services, the topics and problems that had drawn the attention of pediatricians could then be handled by the newly available health care professionals.

\section{REFERENCES}

1. De Asúa M. La pediatría como disciplina cultural y social. Arch Argent Pediatr. 2012; 110(3):231-6.

2. Foucault M. Historia de la medicalización. In La vida de los hombres infames. La Plata: Altamira; 1996.p.85-105.

3. Armus D, Belmartino S. Enfermedades, médicos y cultura higiénica. In: Cattaruzza A (ed.). Nueva Historia Argentina - Tomo 7: Crisis económica, avance del Estado e incertidumbre política (1930 $\square 1943)$. Buenos Aires: Sudamericana; 2001.p.283-329.

4. Vezzetti H. La locura en la Argentina. Buenos Aires: Paidós; 1985.

5. Arditi Rocha R. La educación psicológica del médico. [Teacher Certification Dissertation]. Buenos Aires: Facultad de Ciencias Médicas, UBA; 1942.

6. Rodríguez Sturla P. Sobre la transmisión de la psicología en la Facultad de Ciencias Médicas de la Universidad de Buenos Aires (1940-1957). Temas Hist la Psiquiatr Argentina. 2004; (20):20-5.

7. Mouchet E. Psicología y medicina. De la necesidad de introducir la enseñanza de la psicología en el plan de estudios de la Facultad de Ciencias Médicas de Buenos Aires. Boletín la Soc Psicol Buenos Aires. 1933; I (1930;19:49$56)$.

8. Rimoldi H. Informe sobre la enseñanza de la Psicología Médica en la Facultad de Medicina. Cienc Invest. 1957; 13(4):181-3.

9. Danziger K. The social origins of modern psychology. In: Buss A (ed.). Psychology in Social Context. New York: Irvington; 1979.p.27-45.

10. Danziger K. Towards a conceptual framework for a critical history of psychology. Rev Hist Psicol. 1984; 5(1/2):99-107.

11. Smith R. Between mind and nature: a history of psychology. London: Reaktion Books; 2013.

12. Pickren W, Rutherford A. A History of Modern Psychology in Context. New Jersey: John Wiley \& Sons; 2010.

13. Armus D (ed.). Avatares de la medicalización en América Latina (1870-1970). Buenos Aires: Lugar; 2005.

14. Biernat C, Ramacciotti K (eds.). Historia de la salud y la enfermedad bajo la lupa de las ciencias sociales. Buenos Aires: Biblos; 2014.

15. Belmartino S. La atención médica en Argentina en el siglo $X X$. Instituciones y procesos. Buenos Aires: Siglo Veintiuno; 2005.

16. Rose N. Inventing our Selves. Psychology, Power and Personhood. Cambridge: Cambridge University Press; 1996.

17. Herman E. The Romance of American Psychology. Political
Culture in the Age of Experts. Berkeley: University of California Press; 1995.

18. Brock A (ed.). Internacionalizing the History of Psychology. New York and London: New York University Press; 2006.

19. Aráoz AlfaroG. El cuidado del capital humano. Disertación en el Instituto Popular de Conferencias, Octubre 16 de 1942. Buenos Aires: El Ateneo; 1942:39.

20. Stepan NL. "Thehour of eugenics." Race, gender and nation in Latin America. Ithaca: Cornell University Press; 1991.

21. Armus D. Eugenesia en Buenos Aires: discursos, prácticas, historiografía. Hist Ciênc Saúde - Manguinhos. 2016; 23(Supl):149-69.

22. Chattás A, DeElizaldeF, EscardóF, NottiH. Mesa Redonda: Enseñanza de la Pediatría. In VIII Jornadas Argentinas de Pediatría. Rosario: Sociedad Argentina de Pediatría (Filial Rosario); 1957.p.331-77.

23. Escardó F. La Pediatría, Medicina del Hombre. Diez capítulos para un pediatra joven. Buenos Aires: El Ateneo; 1951.

24. Garrahan JP. La Salud del Hijo. Puericultura. Buenos Aires: El Ateneo; 1955.

25. Talak AM. Eugenesia ehigiene mental: usos de la psicología en la Argentina, 1900-1940. In: Miranda M, Vallejo G (eds.). Darwinismo social y eugenesia en el mundo latino. Buenos Aires: Siglo Veintiuno; 2005.p.563-99.

26. Klappenbach $\mathrm{H}$. El movimiento de la higiene mental y los orígenes de la Liga Argentina de Higiene Mental. Temas Hist la Psiquiatr Argentina. 1999; (10):3-17.

27. Piaggio Garzón W. Reflexiones sobre los diversos aspectos de la orientación actual de la Medicina General y de la Pediatría. Boletín del Inst Int Am Protección a la Infanc. 1939; XII(3):499-531.

28. Lawrence C, Weisz G (eds.). Greater than the parts: holism in biomedicine, 1920-1950. New York: Oxford University Press; 1998.

29. Escardó F. La "Pediatría Psicosomática" como disciplina normativa. Arch Argent Pediatr. 1957; XLVIII(2):67-70.

30. GarrahanJP. Aspectos psicológicos de la técnica alimentaria del niño. Dia Med. 1956; XXVIII(9):185-8.

31. Garrahan JP. La nueva Puericultura. Arch Pediatr Urug. 1955; XXVI(1):128-34.

32. Garrahan JP. Cincuenta Años de Pediatría Argentina. Arch Argent Pediatr. 1962; XXXII(3):89-98.

33. Daniel C. Contar para curar: estadísticas y comunidad médica en Argentina, 1880-1940. Hist Ciênc SaúdeManguinhos. 2012; 19(1):89-114.

34. Biernat C, Ramacciotti K. Crecer y multiplicarse: la política sanitaria materno-infantil. Argentina 1900-1960. Buenos Aires: Biblos; 2013.

35. Nari M. Políticas de maternidad y maternalismo político: Buenos Aires (1890-1940). Buenos Aires: Biblos; 2004.

36. Briolotti AS. La evaluación del desarrollo psicológico en los dispensarios de lactantes de Buenos Aires: medicina y psicología en la Argentina, 1935-1942. Hist Ciênc Saúde Manguinhos. 2016; 23(4):1077-93.

37. Sbarra N, Alcaide A, Carneiro A. Medición del nivel de maduración neuropsíquica en niños de primera infancia internados y en adopción mediante el test de Gesell. Rev la Soc pediatrics La Plata. 1963; XXIV(1):19-34.

38. Moreno de Taubenslag I, Taubenslag L, Méndez A, Burich MT. Mesa Redonda: Desarrollo Psicomotor y Estado Nutritivo. In XIII Jornadas Argentinas de Pediatría. Tucumán: Sociedad Argentina de Pediatría (Filial Tucumán); 1963.p.255-79.

39. Moreno de Taubenslag I, Taubenslag L, Rybak A, Burich MT. Nivel de Maduración Neuropsíquica en la Distrofia Carencial del Lactante. Arch Argent Pediatr. 1963; 34(34):66-72. 
40. Briolotti AS. La Neurología Infantil en su proyección profiláctico-social: Pediatría, Higiene Mental y Psicología en la Argentina (1934-1940). Interface (Botucatu). 2020; 24:e190319.

41. Escardó F, GibertiE. La salud mental en la primera infancia. Rev Asoc Med Argent. 1961; 75(2):66-73.

42. Briolotti AS. El problema del hospitalismo en la medicina infantil rioplatense y el rol de los saberes psi en la subjetivación de la maternidad y la infancia (1933-1965). Rev Ciencias la Salud. 2016; 14(3):453-68.

43. Bowlby J. Los cuidados maternos y la salud mental. Washington: Oficina Sanitaria Panamericana; 1954.

44. De San Martín AM. Anorexia infantil. Arch Argent Pediatr. 1939; 10(2):256-77.

45. Schiavone G. Consideraciones sobre la anorexia infantil. Rev Oral Cienc Méd. 1940; V(54):459-72.

46. Baranchuk M. Consideraciones sobre la anorexia mental de los lactantes. An Soc Pueric B Aires. 1938; IV(4):297-302.

47. BaranchukM,RotmanI.LaInapetenciaylaSeudoinapetencia de los Lactantes. Sem Med. 1951; LVIII(3017):890-3.
48. Buzzo A, Agostini de Muñoz A, Calabrese A. Contribución al estudio de las causas de la aversión del lactante al seno materno. An Soc Pueric B Aires. 1939; V(3):183-6.

49. Padilla Roqué C. Creciendo fuertes. Moderna y práctica guía para el cuidado y la educación de los niños de uno a seis años. Buenos Aires: Orientación Integral Humana; 1941.

50. Escardó F. La inapetencia infantil. Buenos Aires: El Ateneo; 1940.

51. Ugarte F. La conducta alimentaria en el primer trimestre de vida. Rev la Soc Pueric Buenos Aires. 1955; XXI(2):65-75.

52. Ugarte F. Algunos problemas prácticos de puericultura considerados desde el punto de vista psicoanalítico. Rev la Soc Pueric Buenos Aires. 1950; XVI(3):133-42.

53. Rivelis L. El derecho de succión. Nuestros hijos Su educación moral y física. 1956; 80-5.

54. Turró O, Ortiz Á, Nocetti Fasolino J, Garrote R, et al. Mesa Redonda: Asistencia del niño hospitalizado. In: Mazza J, (ed). XJornadas Argentinas dePediatría. La Plata:Sociedad Argentina de Pediatría (Filial La Plata); 1959.p.233-51. 